\title{
Occurrence and comparison of Jerdon's Gecko Hemidactylus subtriedrus Jerdon 1853 with Termite Hill Gecko Hemidactylus triedrus (Daudin 1802) from Ananthagiri Hills, northern Eastern Ghats, India
}

\author{
S.M. Maqsood Javed ${ }^{1}$, S. Saravanan ${ }^{2}$, Farida Tampal ${ }^{2}$ \& C. Srinivasulu ${ }^{3}$ \\ 1,2 World Wide Fund for Nature-India (WWF)- APSO, Ho. No. 818, Castle Hills, Road No. 2, Near NMDC, Vijayanagar Colony, Hyderabad, \\ Andhra Pradesh 500057, India \\ ${ }^{3}$ Wildlife Biology Section, Department of Zoology, University College of Science, Osmania University, Hyderabad, Andhra Pradesh 500007, India \\ Email: ${ }^{1}$ javedwwf2007@gmail.com
}

Date of online publication 26 July 2009 ISSN 0974-7907 (online) | 0974-7893 (print)

Editor: Aaron Bauer

Manuscript details:

Ms \# 02184

Received 24 March 2009

Final received 12 June 2009

Finally accepted 13 July 2009

Citation: Javed, S.M.M., S. Saravanan, F. Tampal \& C. Srinivasulu (2009). Occurrence and comparison of Jerdon's Gecko Hemidactylus subtriedrus Jerdon 1853 with Termite Hill Gecko Hemidactylus triedrus (Daudin 1802) from Ananthagiri Hills, northern Eastern Ghats, India. Journal of Threatened Taxa 1(7): 366-369

Copyright: (C) S.M. Maqsood Javed, S. Saravanan, Farida Tampal \& C. Srinivasulu 2009. Creative Commons Attribution 3.0 Unported License. JoTT allows unrestricted use of this article in any medium for non-profit purposes, reproduction and distribution by providing adequate credit to the authors and the source of publication.

Author Details: See end of this article.

Author Contribution: S.M.M. Javed, S. Saravanan conducted the field surveys; C.Srinivasulu, S.M.M. Javed and F. Tampa wrote the paper.

Acknowledgement: See end of this article.
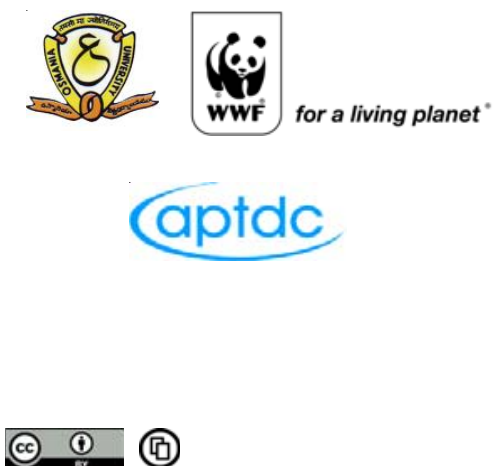

OPEN ACCESS | FREE DOWNLOAD
Abstract: Recent herpetological surveys in northern Eastern Ghats of Andhra Pradesh yielded sightings of Jerdon's Gecko Hemidactylus subtriedrus Jerdon 1853. Little is known about its distribution and taxonomic status. This species closely resembles the Termite Hill Gecko Hemidactylus triedrus (Daudin 1802) and it has often been taxonomically confused with it. Therefore, through this communication we provide information on the occurrence of Jerdon's Gecko along with details showing the level of resemblance and differences from Termite Hill Gecko.

Keywords: Ananthagiri Hills, Andhra Pradesh, Eastern Ghats, Hemidactylus subtriedrus, Hemidactylus triedrus.

Jerdon's Gecko Hemidactylus subtriedrus Jerdon 1853 is one of the rare, endangered and endemic species of India (Molur \& Walker 1998). Little is known about its distribution and taxonomic status (Smith 1935; Zug et al. 2007). This species closely resembles the Termite Hill Gecko Hemidactylus triedrus (Daudin 1802) and it has often been taxonomically confused with it. Recent herpetological surveys in northern Eastern Ghats of Andhra Pradesh yielded sightings of Jerdon's Gecko in February 2009. Through this note, we communicate the occurrence of Hemidactylus subtriedrus from a second location in Andhra Pradesh after Jerdon's discovery in 1853 from the Nellore District (type locality not precise, but accepted as Nellore and Ellore in southern India, the regions adjoining the borders Nellore and Vellore districts of the Madras Presidency of British India).

The Ananthagiri Hill range is located in the northern parts of the Eastern Ghats in Andhra Pradesh. It is an unbroken chain of rugged hills and plateaus that spreads over an area of about $300+\mathrm{km}^{2}$. The river Gosthani bisects the hill ranges. The Ananthagiri Hills possess typical Southern tropical dry deciduous and Southern tropical moist deciduous forest types intermingled with scrub (Champion \& Seth 1968). The importance of this landscape has been recognized internationally with the "Eastern Deccan Plateau moist forests" of northern Eastern Ghats being designated as a "Global 200 Ecoregion" (WWF 2007). The Ananthagiri Hills support a very high biodiversity. The flora is represented by mixture of moist and dry species like Adina cordifolia, Mallotus phillipensis, Pterocarpus marsupium, Terminalia tomentosa, Macaranga peltata, Chloroxylon swietenia, Tectona grandis, Anogeissus latifolia, Ficus benjamina, Ficus hispida, Butea monosperma, Bauhinia semla, Bauhinia racemosa, Bauhinia vahlii, with undergrowth consisting of Bambusa arundinacea, Helecteris isora, Grewia hirsuta, etc. The fauna includes highly threatened species like Panthera pardus, Melursus ursinus, Tetraceros quadricornis, Anthracoceros coronatus, etc. The overall climate of this region is hot and dry most of the year. Air temperature rises to a summer peak of $36^{\circ} \mathrm{C}$ and dips to $5^{\circ} \mathrm{C}$ in winter. The average rainfall is about $900-1500$ mm per annum.

World Wide Fund for Nature - India (WWF), Andhra Pradesh State Office in collaboration with Andhra Pradesh Tourism Development Corporation (APTDC) has initiated a six months (January to August 2009) survey-based biodiversity documentation project in APTDC Eco-tourism sites, which fall within the northern and central Eastern Ghats of Andhra Pradesh. The outcome of these surveys will be documented in the form of a biodiversity field guide for eco-tourism enthusiasts. WWF and APTDC consider that documenting our existing natural heritage is one of the effective methods for its sustainable conservation and management. During the first phase of a biodiversity survey at APTDC eco-tourism sites in the northern Eastern Ghats (Tyda, Borra, Ananthagiri and Araku Valley), we observed a few specimens of Jerdon's Gecko 


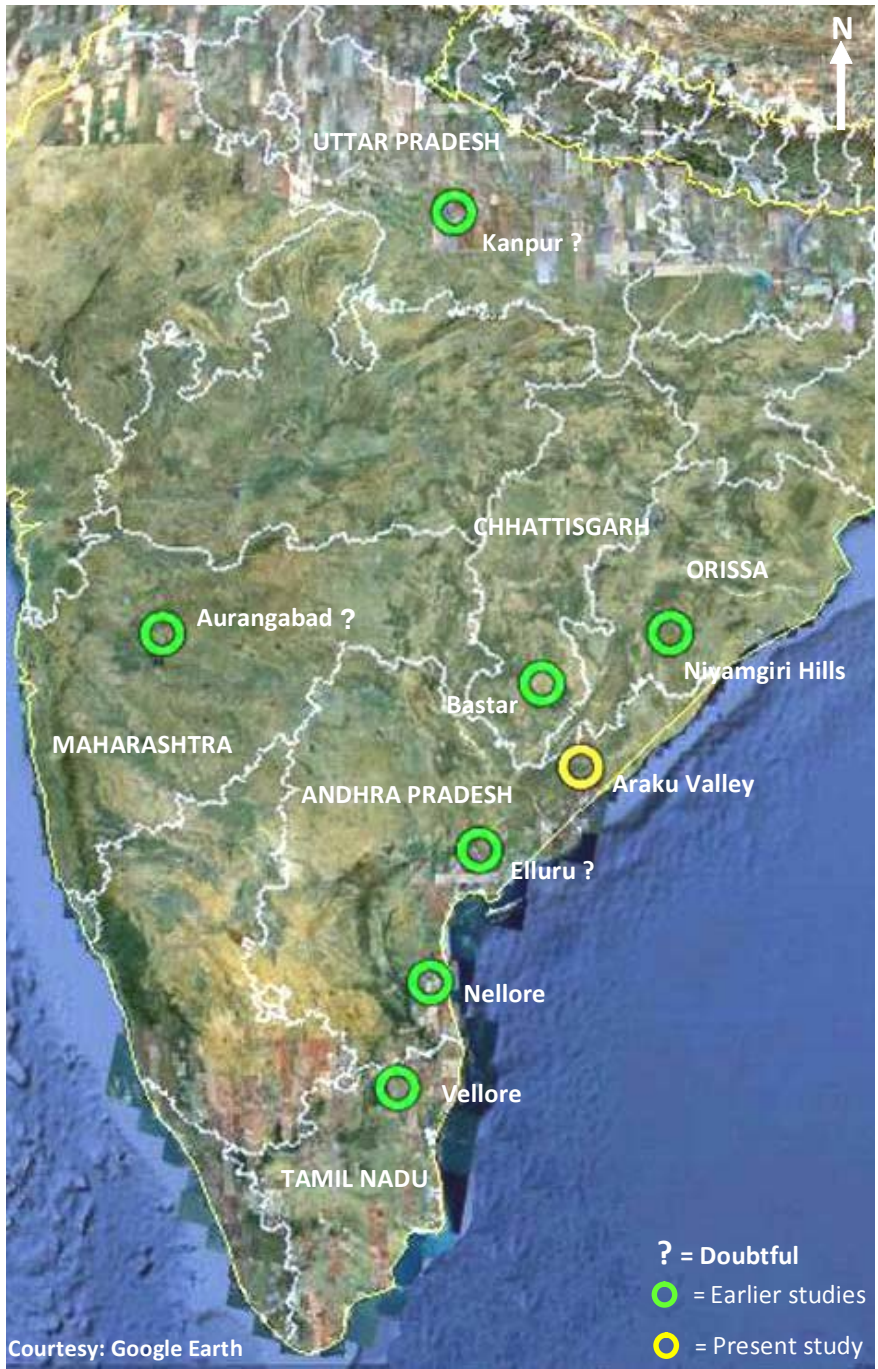

Image 1. Map showing eight distribution sites of Jerdon's Gecko Hemidactylus subtriedrus Jerdon 1853 in six Indian states including Andhra Pradesh, Chhattisgarh, Maharashtra, Orissa, Tamil Nadu \& Uttar Pradesh (not to scale)

Hemidactylus subtriedrus Jerdon, 1853 in the Araku valley $\left(18^{\circ} 20^{\prime} \mathrm{N} \& 82^{\circ} 50^{\prime} \mathrm{E}\right)$ (Image 1). This species is restricted to eastern Andhra Pradesh along the coastal region. It closely resembles Hemidactylus triedrus (Daudin, 1802), which is a widely distributed species in central and western Andhra Pradesh (restricted to Nallamalai Hills and plains of Deccan plateau) and also in other parts of India, as well as Pakistan. An endemic subspecies, H. t. lankae, occurs in Sri Lanka. We provide photo vouchers of both species to show the level of resemblance as well as differences between the two (Images 2 \& 3).

\section{Material and Methods}

We surveyed the study area for three days (between 16 and 18 February 2009 from 2100 to $2300 \mathrm{hr}$ ). During the survey two specimens were encountered and the photo voucher (NHM.OU.REP.PV.1-2009) of one specimen has been deposited in the Natural History Museum of Osmania University, Hyderabad, India. The specimen was captured and released after examination (not sexed), measurement and

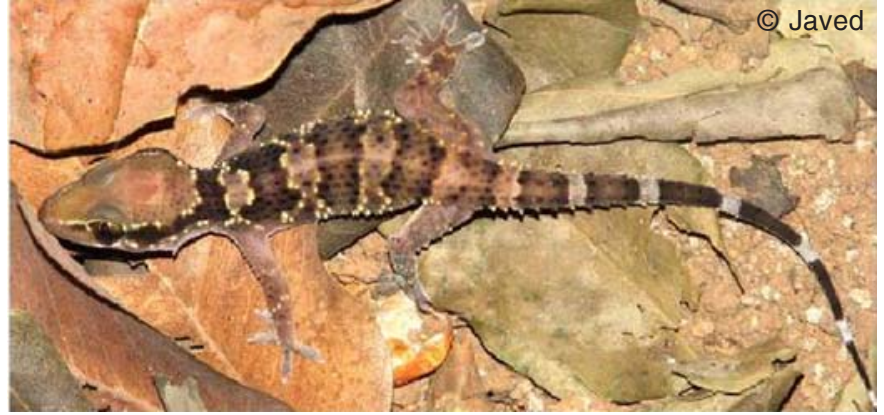

Image 2. Dorsal aspect of Hemidactylus subtriedrus adult in life

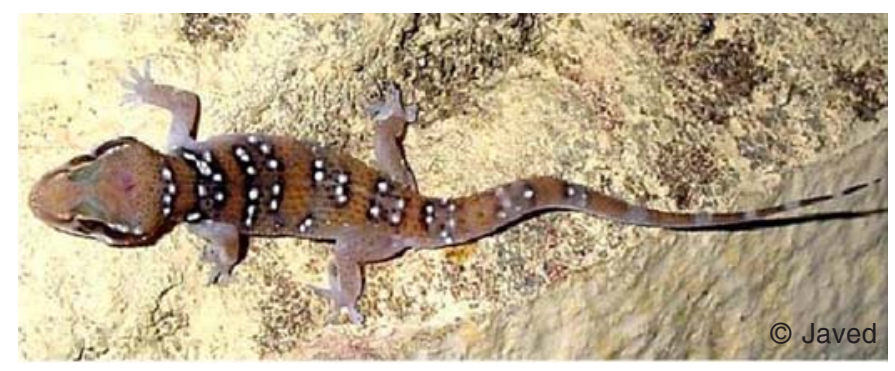

Image 3. Dorsal aspect of Hemidactylus triedrus adult in life

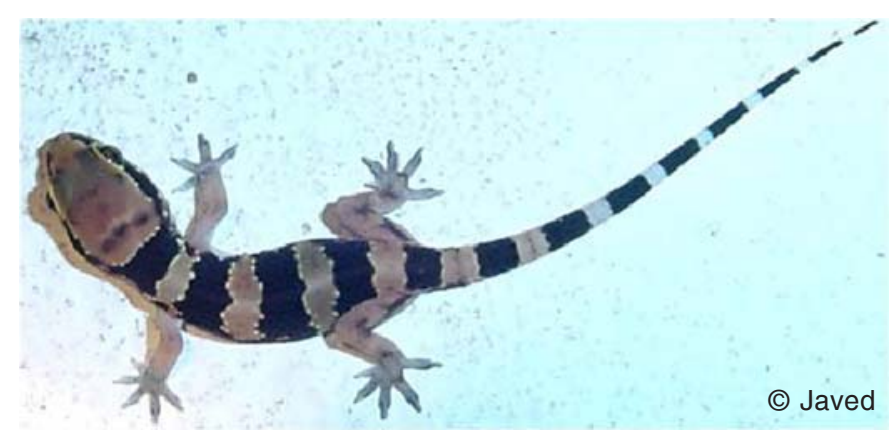

Image 4. Dorsal aspect of Hemidactylus triedrus juvenile in life

photography. The measurements (in $\mathrm{mm}$ ) were taken with Mitutoyo digital calipers (to the nearest $0.1 \mathrm{~mm}$ ): snout-vent length (SVL; from tip of snout to vent) $=60.10$, trunk length (TRL; distance from axilla to groin measured from posterior edge of forelimb insertion to anterior edge of hind limb insertion $)=33.00$, body width (BW; maximum width of body) $=11.78$, crus length $(\mathrm{CL}$; from base of heel to knee) $=6.6$; tail length (TL; from vent to tip of tail $)=69.00$, tail width $(\mathrm{TW}$; measured at widest point of tail) $=4.45$; head length $(\mathrm{HL}$; distance between retroarticular process of jaw and snout-tip) $=12.60$, head width (HW; maximum width of head $)=10.00$, head height ( $\mathrm{HH}$; maximum height of head, from occiput to underside of jaws) $=7.09$, forearm length (FL; from base of palm to elbow $)=4.22$; orbital diameter $(\mathrm{OD}$; greatest diameter of orbit $)=3.00$, nares to eye distance $(\mathrm{NE}$; distance between anteriormost point of eye and nostril $)=5.10$, snout to eye distance (SE; distance between anteriormost point of eye and tip of snout $)=6.15$, eye to ear distance $(\mathrm{EE}$; distance from anterior edge of ear opening to posterior corner of eye) = 4.78 , internarial distance (IN; distance between nares) $=1.50$, interorbital distance (IO; shortest distance between left and 

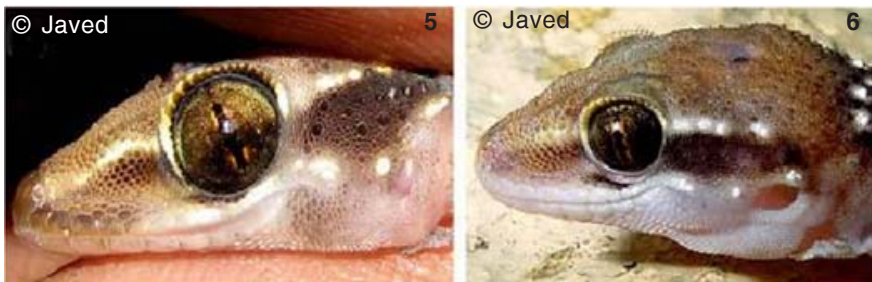

Image 5 - Lateral aspect of Hemidactylus subtriedrus head in life; Image 6 - Lateral aspect of Hemidactylus triedrus head in life
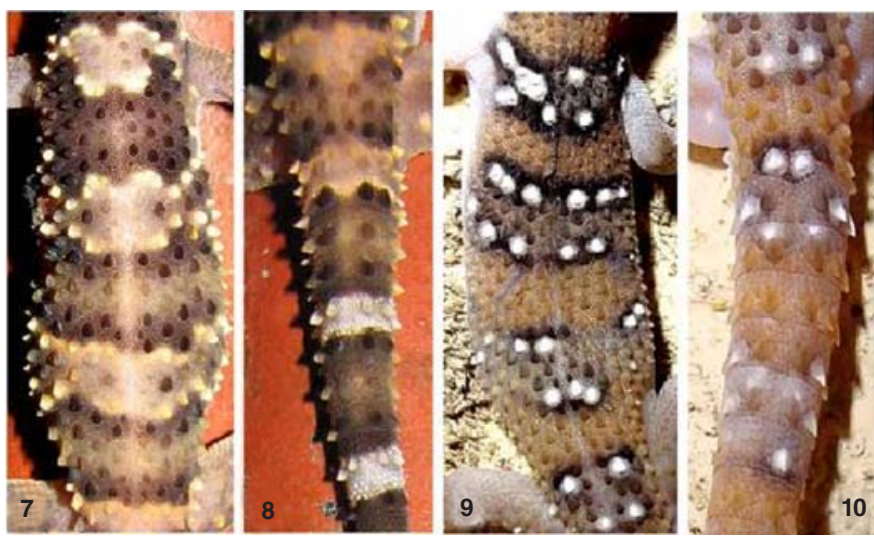

Image 7 - Dorsal aspect of Hemidactylus subtriedrus trunk in life; Image 8 - Dorsal aspect of Hemidactylus subtriedrus tail at base in life; Image 9 - Dorsal aspect of Hemidactylus triedrus trunk in life; Image 10 - Dorsal aspect of Hemidactylus triedrus tail at base in life. $\odot$ Javed
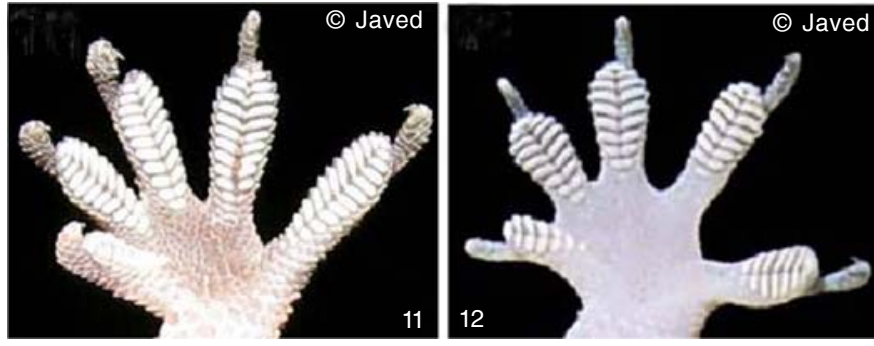

Image 11 - Ventral aspect of Hemidactylus subtriedrus pes showing fourth toe with 12 lamellae in life; Image 12 - Ventral aspect of Hemidactylus triedrus pes showing fourth toe with 9 lamellae in life

right supraciliary scale rows) $=5.60$

\section{DESCRIPTION}

The head is large, oviform and distinct from the neck (Image 2). Snout is longer than the distance between the eye and the ear-opening, l.4 times the diameter of the orbit. Snout covered with convex granules, which may be keeled; hinder part of head with minute granules intermixed with roundish tubercles. Rostral is subquadrangular, not twice as broad as deep (ratio of breadth to depth $<2$ ), with median cleft above; nostril pierced between the rostral and the first labial; 12 upper and 10 lower labials; mental large, triangular or pentagonal, at least twice as long as the adjacent labials; Two pairs of postmentals are present, the outer pair is smaller than the inner. Forehead is concave and ear-opening is narrow, sub-oval, slightly oblique.
Body and limbs moderate. Digits free, moderately dilated, inner well developed; infra-digital lamellae slightly oblique, 8 under the first digit, 12 under the forth. Upper surface of body covered with small flat granular scales, intermingled with large flat scales and large conical tubercles arranged in 16 to 20 more or less irregular longitudinal series. Abdominal scales large, smooth, rounded, imbricate. Tail rounded, feebly depressed, tapering, and covered above with irregular, small as well as large, smooth imbricated scales and rings of large, conical, pointed, keeled tubercles, beneath with a median series of transversely dilated plates. Light pinkish brown above, generally with more or less defined transverse darker bands bordered by pure yellow tubercles surrounded by deep-brown rings. There is no variation observed in comparison to the original description given by Smith (1935).

\section{Comparison of Jerdon's Gecko with Termite Hill Gecko:}

The Jerdon's Gecko differs from that of the Termite Hill Gecko in the following aspects:

1. Forth toe lamellae 12 (vs. $7-10$ lamellae) (Images $11 \& 12$ ). 2. Infralabials 10 (vs. 7-8 infralabials) (Images 5 \& 6).

3. Ear opening narrow, sub-oval and slightly oblique (vs. wide, oval and oblique) (Images $5 \& 6$ ).

4. Dark bands on the dorsum broad, unbroken and with yellow margins (vs. narrow faded bands, each broken distinctly in to two by white tubercles with black margins) (Images 2 \& 3 ).

5. Bands on the body and tail 12 (vs. 14) (Juvenile H. triedrus closely resembles the adult $H$. subtriedrus) (Images 2 to 4 ).

6. Tubercles on the dorsum and tail sparse, conical and straight (vs. dense, trihedral and posteriorly slanting) (Images 7 to 10).

Until now, Jerdon's Gecko had only been recorded from the Nellore district, Andhra Pradesh, and the Vellore district, Tamil Nadu (Smith 1935; Sanyal \& Dasgupta 1990; Sharma 2002). This species has also been reported earlier from Aurangabad, Maharashtra (Anon 1884) and recently reported from Bastar, Chhattisgarh (Sanyal \& Dasgupta 1990; Chandra \& Gajbe 2005); Kanpur, Uttar Pradesh (based on the collection of specimen in 1975 by $\mathrm{S}$. Praveen, deposited in Cornell University Museum of Vertebrates) and Niyamgiri Hills, Rayagada and Kalahandi districts, Orissa (Dutta et al. 2005). Literature references to its occurrence in Ellore, Andhra Pradesh needs to be confirmed as recent surveys in the Elluru region of the Krishna district did not yield H. subtriedrus. We suspect that the Ellore mentioned by Jerdon (1853) and subsequent authors could be Vellore of Tamil Nadu. If that is the case, our observations constitute the second record of this species in Andhra Pradesh, India.

\section{References}

Anon. (1884). Gazetteer of Aurangabad. Published under the orders of his highness the Nizam's Government. Printed at the times of India steam press, Bombay, India, $427 \mathrm{pp}$

Champion, H.G. \& S.K. Seth (1968). A Revised Survey of the Forestry Types of India. Government of India Press, New Delhi, 404pp.

Chandra, K. \& P.U. Gajbe (2005). An inventory of Herpetofauna of Madhya Pradesh and Chhattisgarh. Zoos' Print Journal 20(3): 1812$1819 \mathrm{pp}$.

Dutta, S.K., M. Biswajit \& P.P. Mohapatra (2005). A Brief Report on Ecological and Biodiversity Importance of Niyamgiri Hill and Implications of Bauxite Mining. Environmental Protection Group, Orissa, 1-26pp. Molur, S. \& S. Walker (eds.) (1998). Reptiles of India. Biodiversity 
Conservation Prioritisation Project (BCPP) India, Endangered Species Project-Conservation Assessment and Management Plan (C.A.M.P.) workshops. Zoo Outreach Organisation \& CBSG, India, Coimbatore, India, $175 \mathrm{pp}$.

Praveen, S. (1975). Specimen collection record from Kanpur. Global Biodiversity Information Facility Data Portal. Website <http://www.discoverlife.org/mp/20l? id = GBIF 159082579 $>$ (Accessed on 15 $5^{\text {th }}$ April 2009).

Sanyal, D.P. \& G. Dasgupta (1990). On a collection of Reptiles from Bastar district, Madhya Pradesh, Central India. Hamadryad 15(1): 18-20.

Sharma, R.C. (2002). Fauna of India, Reptilia, Vol. - II, Sauria. Zoological Survey of India, Calcutta, 430pp.

Smith, M.A. (1935). Fauna of British India including Ceylon and Burma. Reptilia and Amphibia. Vol. II, Sauria. Today and Tomorrow's Printers \& Publishers, New Delhi, India Reprint (1974), 440pp.

WWF (2007). Conservation Science, Global 200 Ecoregions. Website: <www. worldwildlife. $\mathrm{org} / \mathrm{science} /$ ecoregions/g200.cfm> (Accessed on 15 $5^{\text {th }}$ April 2009).

Zug, G.R., J.V. Vindum \& M.S. Koo (2007). Burmese Hemidactylus (Reptilia, Squamata, Gekkonidae): taxonomic notes on tropical Asian Hemidactylus. Proceedings of the California Academy of Sciences, Fourth Series, 58, 387-405pp.
Author Details: S.M. MAQsood JAVEd is a Senior Field Researcher cum Education Officer, World Wide Fund for Nature- India (WWF), Andhra Pradesh State Office located at Hyderabad. His interest lies in biodiversity studies with special emphasis on Arachnofauna and Herpetofauna.

S. Sarvanan is Education Officer, World Wide Fund for Nature - India (WWF), Andhra Pradesh State Office located at Hyderabad. His interest lies in Herpetofauna and Ornithology.

FARIDA TAMPAL is State Director of the Andhra Pradesh State Office of World Wide Fund for Nature - India (WWF) located at Hyderabad. She is interested in understanding the biodiversity of the Eastern Ghats with special emphasis on Ecology, Arachnofauna and Herpetofauna.

C. SRInivasulu is Assistant Professor in Department of Zoology of University College of Science, Osmania University in Hyderabad. He is the head of the research laboratory at Osmania University that focuses on biodiversity inventorying, conservation, ecology and animal taxonomy with special reference to Eastern Ghats and Godavari river basin in Andhra Pradesh.

Acknowledgement: The authors are very much thankful to Shri Hitesh Malhotra, IFS, Principal Chief Conservator of Forest (Wildlife) and Chief Wildlife Warden, Andhra Pradesh for constant support and encouragement. SMMJ, SS and FT expresses gratitude to Shri Anil Kumar V. Epur, Chairman, WWFAP State Committee, Hyderabad and Shri Ravi Singh, Secretary General \& CEO, WWF-India, New Delhi for constant support and encouragement. We also express our thanks to Shri Jayesh Ranjan, IAS, Managing Director and Shri P.V. Ramana Reddy, IFS, Executive Director, Andhra Pradesh Tourism Development Corporation, Hyderabad for constant support and permitting us to conduct biodiversity studies in APTDC Eco-tourism sites. CS thanks Prof. T. Tirupathi Rao, Vice Chancellor, Osmania University and the Head, Department of Zoology, Osmania University, Hyderabad for encouragement and facilities. We are also thankful to Dr. Aaron M. Bauer, Herpetologist, Villanova University, USA and Mr. P.P. Mohapatra, Herpetologist and Research Scholar, Orissa for constructive suggestions and helping with references. Lastly, we would like to thank Mr. P.S.M. Srinivas, Manager Corporate for exploring new places and all the WWF-Staff of APSO, Hyderabad for their constant support and timely suggestions. 